\title{
Comparative Study on Biocontrol Potential of Local Isolates with Commercial Formulations of Trichoderma harzianum for the Management of Collar Rot of Chickpea Caused by Sclerotium rolfsii Sacc.
}

\author{
Anil Kumar ${ }^{1}$, Ramesh Singh $\operatorname{Yadav}^{1 *}$, Kamal Khilari ${ }^{1}$, Prashant Mishra ${ }^{1}$, \\ D. V. Singh' ${ }^{2}$ M. K. Yadav ${ }^{3}$ and Amit kumar Yadav \\ ${ }^{1}$ Centre of Excellence for Sanitary and Phytosanitary (SPS), Department of Plant Pathology \\ ${ }^{2}$ Department of Entomology, ${ }^{3}$ Department of Agricultural Biotechnology, Sardar Vallabhbhai \\ Patel University of Agriculture and Technology, Meerut-250110, India \\ *Corresponding author
}

\begin{tabular}{l} 
K e y w o r d s \\
$\begin{array}{l}\text { Chickpea, Collar } \\
\text { rot, Sclerotium } \\
\text { rolfsii, Trichoderma } \\
\text { harzianum and } \\
\text { Vermicompost }\end{array}$ \\
Article Info \\
$\begin{array}{l}\text { Accepted: } \\
\text { 22 July } 2020 \\
\text { Available Online: } \\
\text { 10 August } 2020\end{array}$ \\
\hline
\end{tabular}

\section{A B S T R A C T}

Collar rot disease is a major constraint in chickpea production. Comparative efficacy of local isolates and commercial formulations of Trichoderma harzianum were evaluated in lab and field against collar rot of chickpea caused by Sclerotium rolfsii during 2018-2019. Tested local isolates and commercial formulations significantly inhibited mycelial growth of $S$. rolfsii in-vitro were evaluated in field condition as seed treatment @ $8 \mathrm{gm} / \mathrm{kg}$ seed (cfu $\left.1 \times 10^{8} / \mathrm{gm}\right) \&$ soil treatment @ 5kg/ha (cfu $1 \times 10^{8} / \mathrm{gm}$ ) with $100 \mathrm{~kg}$ vermicompost prior to sowing and recorded the germination percentage, shoot length, root length, nodulation/plant, disease incidence and yield/ha. Maximum seed germination (88\%), nodulation (44/plant), pod (306/plant) and highest yield (21.66 q/h) was recorded in soil treated with local T. harzianum isolate CRC and minimum seed germination (77.33\%), nodulation (20/plant) in seed treated with $T$. harzianum (Bioharz) and lowest yield $(15.83 \mathrm{q} / \mathrm{h}$ ) was observed in soil treated with T. harzianum (Bioharz). Where as Maximum shoot length $(55.33 \mathrm{~cm})$ \& root length $(24.33 \mathrm{~cm})$ was observed in seed treated with local $T$. hargianum isolate $\mathrm{CRC}$ and minimum shoot length $(37.33 \mathrm{~cm}) \&$ root length $(13.33 \mathrm{~cm})$ seed treated with local T. harzianum isolate KVK Hastinapur. Minimum disease incidence (3.57\%) was found soil treated with $T$. harzianum isolate CRC multiplied in vermicmpost and maximum disease incidence $(11.85 \%)$ soil treated with $T$. harzianum commercial formulation (Bioharz). However, local isolates as well as commercial formulation of $T$. harzianum) decreased disease incidence and increased pod yield comparison to control.

\section{Introduction}

Chickpea is an important and major pulse crop throughout the world including India.
Chickpea is a good source of protein for majority of population and used to feed animals. Chickpea is a good source of nutrition among dry edible grain legumes. 
Chickpea seeds contain $17-22 \%$ highly digestible protein, $60.8 \%$ total carbohydrates, $2.70-6.48 \%$ fat (primarily linoleic and oleic acids), $5 \%$ crude fibre, $6 \%$ soluble sugar and $3 \%$ ash (Williams and Singh, 1987). It holds 75 percent production among pulses. There are two types of chickpea cultivated Viz. Desi and Kabuli types. Of them, 85 per cent area occupies Desi types while and remaining area covered by Kabuli types. In India, major chickpea growing states are Madhya Pradesh (MP), Maharashtra, Rajasthan, Uttar Pradesh, Karnataka and Andhra Pradesh and all contributes collectively up to 90 per cent area and 91 per cent production in the country (Singh, 2010). Chickpea covers cultivated area of 105.73 lakh hectares with production of 111.18 lakh tons with productivity level of $1056 \mathrm{~kg} / \mathrm{ha}$ (Anonymous 2018). In Uttar Pradesh, chickpea is grown in 6.11 Lakh hectares area with a total production of 6.84 Lakh tone (Anonymous 2018), while productivity is $901 \mathrm{~kg} / \mathrm{ha}$ (anonymous 2017). Chickpea also helps to maintain the soil health and takes $80 \%$ of its nitrogen $(\mathrm{N})$ needs from symbiotic microbial association. It also gave considerable amount of residual nitrogen to the successive crops and helps to add organic matter to improve the soil health (Saraf et al., 1998).

Chickpea crop affects by different diseases viz., Dry root rot, Fusarium wilt Collar rot, Verticillium wilt, Ascochyta blight, Black root rot, Phytophthora root rot, Grey mould and seed rot. Of them, collar rot (Sclerotium rolfsii Sacc.) is a very damaging to chickpea. Under all favorable conditions, collar rot disease may be a serious threat, which causes very high mortality (55-95\%) at seedling stage of this crop (Gurha and Dubey, 1982). Collar rot is causes high losses in yield and production if persists longer. It is well known fact that collar rot is a soil-borne pathogen and produced symptom on the collar region of the plant that is why named collar rot. It also affects many other plant species of families Leguminosae and Compositae, while Graminae family is less susceptible to collar rot disease (Mahen et al., 1995). Trichoderma and its various species are widely used as a potent biological control agent of soil borne plant pathogens and is a key area of research in the present days in all over the world (Mukhopadyay, 1987). Many research groups confirmed that Trichoderma has potential capacity to control different soil borne plant pathogens (Papavizas, et al., 1984). Trichoderma spp. is among them and recognized as a broad range biological control agent that shows good activity for their growth in soil. In present day agricultural systems, the usage of fungicides has become vital. Seed treatment with combination of fungicides and bio-agents is a common method used in different crops. It alters the microbial symmetry in soil which helps to reduce disease incidence in a particular area. Trichoderma spp., is well proven to establishes symbiotic rather than parasitic relationships among the plant and crop species through increasing plant growth and yield that helps to overcome stress and stimulates nutrient absorption (Harman et al., 2004).

\section{Materials and Methods}

\section{Sample collection, isolation of Trichoderma spp.}

Soil samples from different locations collected for the present investigation. Locations which were used are CRC, HRC, KVK Hastinapur, all comes under jurisdiction of SVPUA\&T, Meerut. Samples were collected randomly with the help of an open soil borer (approx. $20 \mathrm{~cm}$ depth, $2.5 \mathrm{~cm}$ diameter). Collected samples were air-dried at an optimum temperature for 8-10 days and passed through a $0.8 \mathrm{~mm}$ fine mesh sieve. After that, samples were stored in a 
polyethylene bags for further use in the experiment.

\section{Preparation of Trichoderma selective medium}

Di-potassium Hydrogen Phosphate (DHP) $(0.9 \mathrm{~g}$,$) Magnesium Sulphate (0.2 \mathrm{~g})$, Ammonium Nitrate (1.0g), Potassium Chloride $(0.15 \mathrm{~g})$, Glucose (3g), Metalaxyl $(0.3 \mathrm{~g})$, Penta Chloro Nitro Benzene (PCNB) $(0.2 \mathrm{~g})$, Chloromenicol $(0.25 \mathrm{~g})$, Rose Bengal $(0.15 \mathrm{~g})$, Agar -Agar $(15 \mathrm{~g})$ and the required amount of double distilled water $(1000 \mathrm{ml})$ used in the present study.

Prepared medium through mixing of all these ingredients and sterilized them at $121^{\circ} \mathrm{C}$ and $1.1 \mathrm{Kg} / \mathrm{cm}^{2}$ pressure for around 15 minutes with an autoclave. Then cool the medium up to $45-47^{\circ} \mathrm{C}$. After that poured the sterilized medium in a pre sterilized $90 \mathrm{~mm}$ petri plates under laminar air hood and keep them to solidify.

\section{Potato dextrose agar medium recipe}

Take small piece of potato (200 gms) and peeled them, dextrose (20 gms), agar powder (20 gms), and double distilled sterilized water $(1000 \mathrm{ml})$ in a container. Potatoes were cleaned, washed, peeled and chopped into slices. After that $200 \mathrm{gm}$ of these slices were heat boiled in $500 \mathrm{ml}$ of double distilled water and the extract was carefully sieved through clean and intact muslin cloth. Next step is to take dextrose (20 gm), and of agar powder (20 gm) and dissolved in a $500 \mathrm{ml}$ deionized water. Heat slowly and stirred with the help of a glass rod. The potato extract and agar solution mixed and make the final volume $1000 \mathrm{ml}$ by adding deionized distilled water. The conical flasks containing PDA medium were properly sterilized at recommended temperature $\left(121^{\circ} \mathrm{C}\right)$ and $1.1 \mathrm{~kg} / \mathrm{cm}^{2}$ pressure for at least 15 minutes in a autoclave.

\section{Collection of diseased specimens}

The infected chickpea plants produced the typical symptoms of collar rot were collected from 'Crop Research Centre' (CRC) field of University during Rabi season of 2017-18 for isolation of pathogens of Sclerotim rolfsii. The specimens were then brought to the laboratory and examined carefully for symptoms of the disease.

\section{Isolation, purification and identification of the pathogens}

Isolation of the pathogen was done with the help of standard tissue isolation technique. Infected plant parts were thoroughly washed in sterilized water for removing the dust and other surface contaminants. A small portion of diseased parts (only collar region) were cut into very small pieces with the help of a sterilized scalpel. Thereafter, complete surface sterilization was done with 70 percent ethyl alcohol. Then pieces washed thoroughly with sterilized distilled water thrice. A small piece of infected part was transferred in petriplates containing appropriate amount of PDA. Theses plates were incubated carefully at $27 \pm 1^{0} \mathrm{C}$ for 72 hours. The fungal growth, which arose through the infected tissue in the petri plates, was transferred aseptically to a PDA slants and in a petri-plates. The pathogen was identified with various morphological characters.

\section{Pathogenicity test}

The pathogenicity tests were carried out to prove the Koch's postulate (1876). During the experiment inoculums of mycelium bits was mixed into pots filled with the sterilized soil before sowing the seeds and the placement of inoculums near plant after sowing the seeds in pots filled with sterilized soil. Soil (sterilized) was used to fill in $30 \mathrm{~cm}$ diameter earthen pots. Fifteen days old culture were used to 
grow on PDA medium and mixed thoroughly in the upper soil layer at 1 per cent weight basis. Then healthy seeds (six seeds) were used to grow in each pot. Control s was used without adding inoculums in pots. Plants were incubated for 30 days to appear the collar rot symptoms. Infected plants were taken out and washed thoroughly in double distilled water. Re-isolations were done from a artificially infected plants and then isolated culture compared with original culture.

\section{Isolation, identification and purification of local Trichoderma harzianum isolates}

Soil samples were collected from different places and bring to the laboratory. Stock solution was equipped by dissolving $10 \mathrm{~g}$ of soil sample into $90 \mathrm{~mL}$ of distilled water in test tube. Next, serially diluted the samples as $10^{-1}, 10^{-2}$ to $10-5.1 \mathrm{ml}$ of each of the diluted sample was spread on petri dish containing Trichoderma selective medium (Papavizas and Lumsden, 1982). Then Petri plates were incubated in BOD incubator at $28 \pm 1^{\circ} \mathrm{C}$ for 7 days for growth of Trichoderma spp. Purification was made through single spore isolation method (Bisett, 1984) and put at $4{ }^{\circ} \mathrm{C}$ for further use.

\section{Mass multiplication of local Trichoderma harzianum isolates}

Wheat grains were used for mass culture of Trichoderma isolates. Wheat grains were taken carefully and then rinsed with double distilled water to remove dirt and impurities. Then the grains were soaked in water containing sucrose $(2 \%)$ for $6 \mathrm{hrs}$. Drained excess water and then dried under proper shade for reducing the moisture up to 60$70 \% .250 \mathrm{gm}$ of wheat grain were filled up in $500 \mathrm{ml}$ capacity conical flasks. Flasks with wheat grains were plugged and wrapped with silver foil and sterilized in autoclave at $121^{\circ} \mathrm{C}$ temperature (15 lbs pressure/inch ${ }^{2}$ ) for 15 minutes. Sterilized wheat grains inoculated vigorously growing 5 days old culture of Trichoderma isolates. All inoculated conical flasks were incubated at $26 \pm 2{ }^{\circ} \mathrm{C}$ temperature in a BOD incubator. Trichoderma isolates were allowed to grow after 5 to 6 days shaking of the flasks, the surface of all wheat seeds colonized with a good growth of Trichoderma isolates.

Trichoderma harzianum isolates and commercial formulation

Trichoderma harzianum (cfu $1 \times 10^{8} / \mathrm{gm}$ ) isolate CRC, Trichoderma harzianum (cfu $\left.1 \times 10^{8} / \mathrm{gm}\right) \quad$ isolate HRC, Trichoderma harzianum (cfu $1 \times 10^{8 / g m}$ ) isolate KVK Hastinapur, Trichoderma harzianum commercial formulation (cfu $1 \times 10 \quad 8 / \mathrm{gm}$ ) SVPUAT BCA lab and Trichoderma harzianum (cfu 1x10 $\quad 8 / \mathrm{gm})$ commercial formulation (Bioharz) of market were used for further studies nin lab and field conditio.

\section{In-vitro evaluation of local Trichoderma isolates and commercial Trichoderma formulations against pathogen}

Dual culture technique was used to in vitro evaluation of local Trichoderma isolates and also for commercial Trichoderma formulations against pathogen The antagonistic activity of three local Trichoderma harzianum isolates and two commercial Trichoderma harzianum formulation were tested in-vitro in the present study for their ability to inhibit the mycelial growth of Sclerotium rolfsii. A mycelial disc (5 mm.), cut from the actively growing of 5-7 day old culture of pathogen on PDA, was positioned on fresh PDA plate $(3 \mathrm{~cm}$ from centre) then a $5 \mathrm{~mm}$ mycelial disc, which was obtained from a actively growing 5-7 day old culture of fungal bio agents. That were placed $3 \mathrm{~cm}$ away from the mycelial disk of the pathogen. Three replication of each treatment were maintained with one set of control and without inoculating the bio inoculants and 
plates were incubated at $26 \pm 1{ }^{0} \mathrm{C}$. The radial growth of pathogen was measured after 48, 96, 144, and 196 hours well after incubation.

Inhibition percent of the growth in compare to control was calculated with the help of equation given mentioned by Vincent (1927).

$\mathrm{I}=\frac{\mathrm{C}-\mathrm{T}}{\mathrm{C}} X 100$

Where,

I represent percent inhibition

C represents growth (control)

$\mathrm{T}$ represents growth (treatment)

Thereafter, evaluation of local Trichoderma isolates was done with Trichoderma harzianum for commercial formulation to manage collar rot (Scelorotium rolfsii) under field conditions.

Field experiment was conducted as Randomized Block Design (RBD) with three replications. One treatment served as control which was without any treatment and plot size was kept $3 \times 4 \mathrm{~cm}^{2}$.

\section{Statistical analysis}

Data were analyzed statistically and presented in tables 1, 2 and 3. The data on experiments conducted in the laboratory, pots and field were subjected to statistical analysis. The data were transformed whenever required. The critical difference was worked out at 5.0 per cent probability level to find out the difference between treatments (Chandel, 1993).

\section{Results and Discussion}

In-vitro evaluation for commercial formulation of Trichoderma harzianum against Sclerotium rolfsii

Antagonistic activities of three local isolates and two commercial formulations of
Trichoderma harzianum were used to evaluate against Sclerotium rolfsii in-vitro. Data presented in Table 1 showed that there are significant differences in mycelial growth inhibition of Sclerotium rolfsii in all the tested bio-agents in the present study. Among them, up to or at 196 hours, maximum inhibition $(71.85 \%)$ was recorded in commercial formulation of $T$. harzianum (zharioB) followed by $(71.11 \%)$ in commercial formulation of Trichoderma harzianum obtained from biocontrol lab SVPUAT, Meerut. In case of $T$. harzianum, isolate collected from HRC Meerut and isolate from KVK Hastinapur were found same mycelial inhibition (68.88\%). Minimum (57.07\%) inhibition was observeded in $T$. harzianum isolate of CRC Meerut. All the tested bioagents showed significant inhibition of Sclerotium rolfsii growth over control.

Effect of seed treatment and soil application for commercial formulations of Trichoderma harzianum on different traits Germination percentage

Our findings revealed that percent seed germination varied and were observed from 88 to 65.33 percent. Maximum seed germination $(88 \%)$ was observed in soil application of Trichoderma harzianum followed by seed treatment $(86.33 \%)$ with $T$. harzianum isolate of CRC, while $85.67 \%$ in both soil application \& seed treatment with $T$. harzianum isolate of $\mathrm{KVK}$, Hastinapur. While, seed treatment with commercial formulation of $T$. harzianum BCA lab and soil application, of commercial formulation $T$. harzianum Bioharz the percent seed germination was recorded $82.33 \%$ and $80.00 \%$ respectively (Table 2 ). The lowest germination percent $(77.33 \%)$ was observed in seed treatment with commercial formulation $T$. harzianum Bioharz as compared to control65.33\%. 


\section{Shoot length}

Data in table 2 indicated that the shoot length varied from $53.33 \mathrm{~cm}$ to $33.67 \mathrm{~cm}$. The highest shoot length $(55.33 \mathrm{~cm})$ was recorded in seed treatment with Trichoderma harzianum isolate of CRC followed by $(51.33 \mathrm{~cm})$ soil application of $T$. harzianum isolate KVK, Hastinapur $(49.00 \mathrm{~cm})$ with proper soil application of T. harzianum isolate of HRC and $46.67 \mathrm{~cm}$ in soil application of $T$. harzianum commercial formulation Bioharz. In case of seed \& soil treatment with $T$. harzianum commercial formulation BCA lab shoot length was observed $46.33 \mathrm{~cm}$ and $45.67 \mathrm{~cm}$, respectively. The minimum shoot length was recorded $37.33 \mathrm{~cm}$ in seed treatment with $T$. harzianum isolate $\mathrm{KVK}$ compare to $33.67 \mathrm{~cm}$ in untreated control.

\section{Root length}

In the present study we observed that the root length varied between $26.00 \mathrm{~cm}$ to $13.00 \mathrm{~cm}$ and maximum root length $(26.00 \mathrm{~cm})$ was observed in soil application of Trichoderma harzianum commercial formulation Bioharz followed by $24.33 \mathrm{~cm}$ in seed treatment with T. harzianum isolate of CRC. Average $20.66 \mathrm{~cm}$ root length was recorded in soil application of $T$. harzianum commercial formulation BCA lab and $19.00 \mathrm{~cm}$ in seed treatment with $T$. harzianum isolate of HRC. $18.00 \mathrm{~cm}$ and $17.66 \mathrm{~cm}$ root length was recorded in seed treatment with $T$. harzianum commercial formulation Bioharz and commercial formulation BCA lab, respectively (Table 2). The minimum root length was recorded $(13.33 \mathrm{~cm})$ in seed treatment with $T$. harzianum isolate of KVK in compare to $13.00 \mathrm{~cm}$ in untreated control.

\section{Nodule formation}

Present investigation observations indicate that the number of nodules per plant varied and recorded in the range of 44 to 18 . Maximum number of nodules (44/plant) was recorded in soil application of Trichoderma harzianum isolate of CRC followed by 41/plant in seed treatment with $T$. harzianum isolate of CRC, while 32 and 31 per plant in seed and soil treatment with $T$. harzianum commercial formulation BCA lab, respectively. Seed treatment with $T$. harzianum isolate HRC nodulation was evaluated 30/plant and 28/plant soil application of Trichoderma harzianum isolate of KVK Hastinapur. The minimum nodule formation was recorded (20/plant) in seed treatment with $T$. harzianum commercial formulation Bioharz compare to 18/plant untreated control (Table 2).

Effect of seed treatment and soil application of local isolates and commercial formulations of Trichoderma harzianum against collar rot

\section{Disease incidence}

Our study revealed that all treatment were significantly reduced the disease incidence in compare to control. Disease incidence was reduces to a minimum level of $3.57 \%$ that is recorded in soil application of Trichoderma harzianum isolate of CRC followed by $4.05 \%$ seed treatment with $T$. harzianum isolate of CRC. Disease incidence recorede at the level of $4.22 \%$ and $4.42 \%$ with soil application and seed treatment with $T$. harzianum isolate of HRC, respectively. With reference to the case of seed treatment with $T$. harzianum isolate of KVK Hastinapur, $5.77 \%$ disease incidence was recorded, on the other hand $7.50 \%$ seed treatment with $T$. harzianum for commercial formulation BCA lab was observed. The maximum disease incidence $(11.85 \%)$ was recorded in soil application of $T$. harzianum commercial formulation Bioharz compared to $41.10 \%$ in untreated control at 60 days after sowing (Table 3). 


\section{Yield}

Yield in the present study is represented in q/ha: Data in table 3 revealed that the yield varied between $14.80 \mathrm{q} / \mathrm{ha}$ to $21.66 \mathrm{q} / \mathrm{ha}$. Highest yield (21.66q/ha) was recorded in soil application of Trichoderma harzianum isolate CRC followed by $19.72 \mathrm{q} /$ ha seed treatment with T. harzianum isolate CRC, $18.89 \mathrm{q} / \mathrm{ha}$ soil application of $T$. harzianum isolate HRC and $17.78 \mathrm{q} / \mathrm{ha}$ seed treatment with $T$. harzianum commercial formulation BCA lab. In case of seed treatment with $T$. harzianum isolate HRC and isolate KVK same yield $(17.50 \mathrm{q} / \mathrm{ha})$ was recorded. The lowest yield $(15.83 \mathrm{q} / \mathrm{ha})$ was recorded in soil application of $T$. harzianum commercial formulation Bioharz compare to $14.80 \mathrm{q} / \mathrm{ha}$ untreated control.

Table.1 In-vitro evaluation of different of local Trichoderma harzianum isolates and commercial formulations of Trichoderma harzianum against Sclerotium rolfsii

\begin{tabular}{|c|c|c|c|c|c|c|c|c|c|}
\hline \multirow{2}{*}{$\begin{array}{l}\text { Treatm } \\
\text { ent No. }\end{array}$} & \multirow[t]{2}{*}{ Treatment Details } & \multicolumn{8}{|c|}{ Mycelial growth (mm) } \\
\hline & & $\begin{array}{l}\text { Mycelium } \\
\text { growth } \\
(48 \mathrm{hr})\end{array}$ & $\begin{array}{c}\text { Inhibition } \\
\text { percent }\end{array}$ & $\begin{array}{l}\text { Mycelium } \\
\text { growth } \\
(96 \mathrm{hr})\end{array}$ & $\begin{array}{c}\text { Inhibition } \\
\text { percent }\end{array}$ & $\begin{array}{l}\text { Mycelium } \\
\text { growth (144 } \\
\mathrm{hr})\end{array}$ & $\begin{array}{c}\text { Inhibition } \\
\text { percent }\end{array}$ & $\begin{array}{l}\text { Mycelium } \\
\text { growth } \\
(196 \mathrm{hr})\end{array}$ & $\begin{array}{c}\text { Inhibition } \\
\text { percent }\end{array}$ \\
\hline $\mathbf{T}_{1}$ & $\begin{array}{l}\text { Trichoderma harzianum } \\
\text { isolate-CRC Meerut } \\
\left(\mathrm{cfu} 1 \times 10^{8} / \mathrm{gm}\right)\end{array}$ & 32.33 & 52.91 & 38 & 57.77 & 31.67 & 64.82 & 28.67 & 57.07 \\
\hline $\mathbf{T}_{2}$ & $\begin{array}{l}\text { Trichoderma harzianum } \\
\text { isolate-HRC Meerut(cfu } \\
\left.1 \times 10^{8} / \mathrm{gm}\right)\end{array}$ & 33.67 & 50.97 & 37.33 & 58.52 & 32 & 64.44 & 28 & 68.88 \\
\hline $\mathbf{T}_{\mathbf{3}}$ & $\begin{array}{l}\text { Trichoderma harzianum } \\
\text { isolate-KVK Hastinapur } \\
\left.\text { (cfu } 1 \times 10^{8} / \mathrm{gm}\right)\end{array}$ & 30.33 & 51.45 & 38.33 & 57.41 & 31.33 & 65.18 & 28 & 68.88 \\
\hline $\mathbf{T}_{4}$ & $\begin{array}{l}\text { Trichoderma harzianum } \\
\text {,formulation BCA lab } \\
\text { SVPUAT, Meerut } \\
\left.\text { (cfu } 1 \times 10^{8} / \mathrm{gm}\right)\end{array}$ & 30.00 & 56.30 & 36.67 & 59.26 & 29.33 & 67.41 & 26 & 71.11 \\
\hline $\mathbf{T}_{5}$ & $\begin{array}{l}\text { Trichoderma harzianum } \\
\text { formulation of Market } \\
\text { Bioharz }\left(\mathrm{cfu} 1 \times 10^{8} / \mathrm{gm}\right)\end{array}$ & 31.33 & 54.36 & 38 & 57.77 & 28.33 & 68.52 & 25.33 & 71.85 \\
\hline \multirow[t]{3}{*}{$\mathbf{T}_{6}$} & Control & 68.67 & - & 90 & - & 90 & - & 90 & - \\
\hline & C.D. at $5 \%$ & 4.06 & - & 4.34 & - & 7.71 & - & 6.21 & - \\
\hline & S.E. $(m) \pm$ & 1.30 & - & 1.39 & - & 2.47 & - & 1.99 & - \\
\hline
\end{tabular}


Table.2 Effect of seed treatment and soil application of local Trichoderma harzianum isolates and commercial formulations of Trichoderma harzianum on plant growth parameter of chickpea

\begin{tabular}{|c|c|c|c|c|c|}
\hline $\begin{array}{c}\text { Treatment } \\
\text { No. }\end{array}$ & Treatment Details & $\begin{array}{c}\text { Germination } \\
(\%)\end{array}$ & $\begin{array}{l}\text { Shoot } \\
\text { length } \\
(\mathrm{cm})\end{array}$ & $\begin{array}{l}\text { Root } \\
\text { length } \\
(\mathbf{c m})\end{array}$ & $\begin{array}{c}\text { No. of } \\
\text { Nodules/plant }\end{array}$ \\
\hline $\mathbf{T}_{1}$ & $\begin{array}{l}\text { Soil application of Trichoderma harzianum isolate CRC } \\
\left.\text { Meerut (cfu } 1 \times 10^{8} / \mathrm{gm}\right) \text { (@ } 5 \mathrm{~kg} / \mathrm{ha} \text {. with } 100 \mathrm{~kg} \\
\text { vermicompost) }\end{array}$ & 88 & 45.00 & 15.00 & 44.00 \\
\hline $\mathbf{T}_{2}$ & $\begin{array}{l}\text { Seed treatment with Trichoderma harzianum isolate CRC } \\
\text { Meerut (cfu 1x10 } / \mathrm{gm}) @ 8 \mathrm{gm} / \mathrm{kg} \text { seed }\end{array}$ & 86.33 & 55.33 & 24.33 & 41.00 \\
\hline $\mathbf{T}_{3}$ & $\begin{array}{l}\text { Soil application of Trichoderma harzianum isolate HRC } \\
\left.\text { Meerut (cfu } 1 \times 10^{8} / \mathrm{gm}\right) \text { (@ } 5 \mathrm{~kg} / \mathrm{ha} \text {. with } 100 \mathrm{~kg} \\
\text { vermicompost) }\end{array}$ & 83.67 & 49.00 & 16.33 & 27.00 \\
\hline $\mathbf{T}_{\mathbf{4}}$ & $\begin{array}{l}\text { Seed treatment with Trichoderma harzianum isolate HRC } \\
\text { Meerut (cfu 1x10 } / \mathrm{gm}) @ 8 \mathrm{gm} / \mathrm{kg} \text { seed }\end{array}$ & 81 & 42.00 & 19.00 & 30.00 \\
\hline$T_{5}$ & $\begin{array}{l}\text { Soil application of Trichoderma harzianum isolate KVK } \\
\left.\text { Hastinapur (cfu } 1 \times 10^{8} / \mathrm{gm}\right) \text { (@ } 5 \mathrm{~kg} / \mathrm{ha} \text {. with } 100 \mathrm{~kg} \\
\text { vermicompost }\end{array}$ & 85.67 & 51.33 & 16.33 & 28.00 \\
\hline$T_{6}$ & $\begin{array}{l}\text { Seed treatment with Trichoderma harzianum isolate KVK } \\
\left.\text { Hastinapur (cfu } 1 \times 10^{8} / \mathrm{gm}\right) @ 8 \mathrm{gm} / \mathrm{kg} \text { seed }\end{array}$ & 85.67 & 37.33 & 13.33 & 21.00 \\
\hline $\mathbf{T}_{7}$ & $\begin{array}{l}\text { Soil application of Trichoderma harzianum formulation BCA } \\
\text { lab, SVPUAT, Meerut (cfu 1x10\%/gm) (@ } 5 \mathrm{~kg} / \mathrm{ha} \text {. with 100kg } \\
\text { vermicompost }\end{array}$ & 80.00 & 45.67 & 20.66 & 31.00 \\
\hline $\mathbf{T}_{8}$ & $\begin{array}{l}\text { Seed treatment with Trichoderma harzianum formulation } \\
\text { BCA lab, SVPUAT, Meerut(cfu 1x10 } / \mathrm{gm}) @ 8 \mathrm{gm} / \mathrm{kg} \text { seed }\end{array}$ & 82.33 & 46.33 & 17.66 & 32.00 \\
\hline $\mathbf{T}_{9}$ & $\begin{array}{l}\text { Soil application of Trichoderma harzianum formulation } \\
\left.\text { Bioharz (cfu } 1 \times 10^{8} / \mathrm{gm}\right) \quad(@ 5 \mathrm{~kg} / \mathrm{ha} \text {. with } 100 \mathrm{~kg} \\
\text { vermicompost }\end{array}$ & 80.00 & 46.67 & 26.00 & 24.00 \\
\hline$T_{10}$ & $\begin{array}{l}\text { Seed treatment with Trichoderma harzianum formulation } \\
\left.\text { Bioharz (cfu } 1 \times 10^{8} / \mathrm{gm}\right) @ 8 \mathrm{gm} / \mathrm{kg} \text { seed }\end{array}$ & 77.33 & 45.67 & 18.00 & 20.00 \\
\hline \multirow[t]{3}{*}{$\mathbf{T}_{11}$} & Control & 65.33 & 33.67 & 13.00 & 18.00 \\
\hline & C.D. at $5 \%$ & 4.66 & 4.10 & 3.34 & 2.11 \\
\hline & S.E. $(m) \pm$ & 1.56 & 1.38 & 1.12 & 0.71 \\
\hline
\end{tabular}


Table.3 Effect of seed treatment and soil application of local Trichoderma harzianum isolates and commercial formulations of Trichoderma harzianum on yield and disease incidence of chickpea

\begin{tabular}{|c|c|c|c|c|}
\hline $\begin{array}{l}\text { Treatment } \\
\quad \text { No. }\end{array}$ & Treatment Details & $\begin{array}{c}\text { Disease } \\
\text { incidence } \\
(\%)\end{array}$ & $\begin{array}{l}\text { Yield } \\
(\mathbf{q} / \mathbf{h a})\end{array}$ & $\begin{array}{l}\text { Increase in } \\
\text { yield }(\%)\end{array}$ \\
\hline $\mathbf{T}_{1}$ & $\begin{array}{l}\text { Soil application of Trichoderma harzianum isolate CRC Meerut (cfu } \\
1 \times 10^{8} / \mathrm{gm} \text { ) (@ 5kg/ha. with 100kg vermicompost }\end{array}$ & 3.57 & 21.66 & 46.35 \\
\hline $\mathbf{T}_{2}$ & $\begin{array}{l}\text { Seed treatment with Trichoderma harzianum isolate CRC Meerut } \\
\left.\text { (cfu } 1 \times 10^{8} / \mathrm{gm}\right) @ 8 \mathrm{gm} / \mathrm{kg} \text { seed }\end{array}$ & 4.05 & 19.72 & 33.24 \\
\hline $\mathbf{T}_{3}$ & $\begin{array}{l}\text { Soil application of Trichoderma harzianum isolate HRC Meerut (cfu } \\
1 \times 10^{8} / \mathrm{gm} \text { ) (@ } 5 \mathrm{~kg} / \mathrm{ha} \text {. with } 100 \mathrm{~kg} \text { vermicompost }\end{array}$ & 4.22 & 18.89 & 27.63 \\
\hline $\mathbf{T}_{4}$ & $\begin{array}{l}\text { Seed treatment with Trichoderma harzianum isolate HRC Meerut } \\
\left.\text { (cfu } 1 \times 10^{8} / \mathrm{gm}\right) @ 8 \mathrm{gm} / \mathrm{kg} \text { seed }\end{array}$ & 4.42 & 17.50 & 18.24 \\
\hline $\mathbf{T}_{5}$ & $\begin{array}{l}\text { Soil application of Trichoderma harzianum 1solate KVK Hastinapur } \\
\text { (cfu } 1 \times 10^{8} / \mathrm{gm} \text { ) (@ 5kg/ha. with } 100 \mathrm{~kg} \text { vermicompost }\end{array}$ & 8.16 & 16.11 & 8.85 \\
\hline $\mathbf{T}_{6}$ & $\begin{array}{l}\text { Seed treatment with Trichoderma harzianum isolate KVK } \\
\left.\text { Hastinapur (cfu } 1 \times 10^{8} / \mathrm{gm}\right) @ 8 \mathrm{gm} / \mathrm{kg} \text { seed }\end{array}$ & 5.77 & 17.50 & 18.24 \\
\hline $\mathbf{T}_{7}$ & $\begin{array}{l}\text { Soil application of Trichoderma harzianum formulation BCA lab } \\
\text { SVPUAT(cfu } 1 \times 10^{8} / \mathrm{gm} \text { ) (@ } 5 \mathrm{~kg} / \mathrm{ha} \text {. with 100kg vermicompost }\end{array}$ & 9.24 & 16.38 & 10.67 \\
\hline $\mathbf{T}_{8}$ & $\begin{array}{l}\text { Seed treatment with Trichoderma harzianum formulation BCA lab } \\
\text { SVPUAT (cfu } 1 \times 10^{8} / \mathrm{gm} \text { ) @ } 8 \mathrm{gm} / \mathrm{kg} \text { seed }\end{array}$ & 7.50 & 17.78 & 20.13 \\
\hline $\mathbf{T}_{9}$ & $\begin{array}{l}\text { Soil application of Trichoderma harzianum formulation Bioharz (cfu } \\
\left.1 \times 10^{8} / \mathrm{gm}\right) @ 5 \mathrm{~kg} / \mathrm{ha} \text {. with } 100 \mathrm{~kg} \text { vermicompost }\end{array}$ & 11.85 & 15.83 & 6.95 \\
\hline$T_{10}$ & $\begin{array}{l}\text { Seed treatment with Trichoderma harzianum formulation Bioharz } \\
\left.\text { (cfu } 1 \times 10^{8} / \mathrm{gm}\right) @ 8 \mathrm{gm} / \mathrm{kg} \text { seed }\end{array}$ & 8.55 & 16.25 & 9.79 \\
\hline \multirow[t]{3}{*}{$T_{11}$} & Control & 40.10 & 14.80 & 0.00 \\
\hline & C.D. at $5 \%$ & 5.44 & 2.22 & \\
\hline & S.E. $(\mathrm{m}) \pm$ & 1.83 & 0.74 & \\
\hline
\end{tabular}

In present study compare the efficacy of potent isolates and commercial formulation of Trichoderma harzianum. In vitro there is significant difference in percent inhibition of mycelial growth of Sclerotium rolfsii was recorded by all the tested bio-agents up to 196 hours. Maximum inhibition $71.85 \%$ of Sclerotium rolfsii was recorded in Trichoderma harzianum commercial formulation from market (Bioharz). Similar to our findings Nagamma and Nagaraja (2015) evaluated antagonistic effect of $T$. harzianum against under in-vitro conditions and representing the same line of research confirmation. They observed that the maximum inhibition (71.67\%) of mycelial growth of $S$. rolfsii along with $T$. harzianum (Bacteriology lab isolate) followed by $T$. 
viride (Microbiology lab isolate) $63.33 \%$. Least inhibition was recorded with $T$. harzianum isolate GKVK (31.67\%). Gaikwad et al., (2018) also evaluated antagonistic activity of Trichoderma harzianum against soil borne pathogens under in-vitro conditions. They observed that the maximum mycelial inhibition against $F$ usarium roseum $(62.18 \%)$ and minimum against Sclerotium rolfsii $(27.73 \%)$ in their findings. Yaqub and Shahzad (2005) evaluated in a different finding that Trichoderma harzianum and $T$. longibrachiatum against $S$. rolfsii in-vitro and observed sharp inhibition of the mycelial growth of $S$. rolfsii. The observations of our findings are on the similar track and showed similarity with the findings of many research groups.

In field condition, effective local isolates were evaluated for comparison with commercial formulation. The result was significant increase in the growth parameter i.e. germination, shoot length, root length, number of nodule and number of branch in chickpea plant. The maximum germination percentage $88.00 \%$ and maximum number of nodules 44.33 were recorded in Soil application of Trichoderma harzianum isolate (CRC Meerut) @ 5kg/ha with $100 \mathrm{~kg}$ vermicompost. Maximum shoot length $55.33 \mathrm{~cm}$ was recorded in Seed treatment with Trichoderma harzianum isolate (CRC Meerut) $8 \mathrm{gm} / \mathrm{kg}$ seed. In the similar line of our findings, Pandey and Pandey (2005) evaluated that tomato seeds coated with $T$. viride was very much effective against $S$. rolfsii with 80.8 per cent seed germination. They also observed that Trichoderma treated seed resulted higher germination up to $48.62 \%$ in compare to that of control. Subash et al., (2014) observed the growth and sporulation of $T$. harzianum was faster in sugercane baggase followed by vemicompost, talcum powder and paddy straw in the similar conditions as ours. They also applied $T$. harizanum and mass multiplied with sugarcane baggase directly to the soil and observed that on 7 th week, maximum plant height $(25 \%)$, maximum root length $(12 \%)$ and more nodules $(10 \%)$ were recorded in compare to control. The work of above scientists showed similarity with the present work.

Effect of seed treatment and soil application of local Trichoderma harzianum isolates and commercial formulations of Trichoderma harzianum from market significantly reduced the disease incidence and enhance the yield as compare to control. The minimum disease incidence $3.57 \%$ and maximum yield 21.66 $\mathrm{q} / \mathrm{ha}$ were recorded in soil application of Trichoderma harzianum isolate (CRC Meerut)@5kg/ha with 100kg vermicompost. The maximum disease incidence $11.85 \%$ and minimum yield $15.83 \mathrm{q} / \mathrm{ha}$ was recorded in Soil application of Trichoderma harzianum formulation commercial formulation from market (Bioharz) @ 5kg/ha with $100 \mathrm{~kg}$ vermicompost and $41.10 \%$ was recorded in case of control. Similarly, Singh et al., (2014) have shown the effects of two isolate of Trichoderma spp. against Sclerotium rolfsii under field conditions. They also observed that the use of mixture of two compatible Trichoderma isolates and proved to be the one of the best crop protection strategies for the management of Sclerotia rofsii. Hossain and Hossain (2010) formulated a Trichoderma based BAU-bio fungicide that was found effective against tikka disease of groundnut, foot and root rot of pulses and diseases of some vegetable crops. Sultana and Ahsan et al., (2018) observed that maize grain based culture of T. harzianum @ 5, 10,15 and $20 \mathrm{~g}$ per pot and showed significant reduction in mortality of chickpea seedlings with the application of $S$. rolfsii. Minimum mortality of collar rot $(53.33 \%)$ was evident in the treatment with T. harzianum applied @20 g per pot. Our findings indicates that 
application of these micro-organisms successfully reduce the collar rot incidence and consequently increase the growth of chick pea.

Similarly, Sultana and Hossain (1999) evaluated Trichoderma harzianum for controlling of foot and root rot (Sclerotium rolfsii) of Lentil cv. BARI Masur-1 under field condition. They observed seeds treated with Trichoderma harzianum resulted yield up to $1783.33 \mathrm{~kg} / \mathrm{ha}$ that accounted $81.60 \%$ higher yield over control. Mawar et al., (1918) evaluated efficient bio-formulated product of $T$. harzianum and Bacillus firmus against dry root rot of guar, and sesame caused by Macrophomina phaseolina during rainy season in the year of 2017 at farmer's field. In a study, they also revealed that seed treatment with $T$. harzianum drastically increased yield (14.9-19.0\%) with respect to control. However, result of the work carried out by above scientists showed similarity with the present work.

Present study concluded that seed treatment and soil application of Trihoderma harzianum is an effective method for management of color rot disease of chickpea. The formulation of Trichoderma harzianum (Bioharz) taken from market were also found superior in lab conditions over local Trichoderma harzianum isolates. But under field condition local Trichoderma harzianum isolates were found more effective in compare to commercial formulations of Trichoderma harzianum (Bioharz). Therefore, local isolates of Trichoderma harzianum needs to be conserved, formulated, CIB registration under section 9(3B) \& 9(3) of the insecticide act 1968 , commercially produced by the firms is required to make them available to the end users/famers for the management of soil borne diseases in the field, because local isolates can tolerate adverse climatic conditions prevailing during crop growth.

\section{Acknowledgement}

The authors are heartily acknowledged to the Chief Secretary, Government of U.P. and Director of Agriculture, Government of Uttar Pradesh for providing financial assistance to establish Centre of Excellence for Sanitary and Phytosanitary (SPS) under RKVY scheme (Grant No 2235/12-03-11100(5)/2011 T.C. dated 20-09-2011, Sanction amount Rs. 200 lakh) in the Department of Plant Pathology, Sardar Vallabhbhai Patel University of Agriculture and Technology Meerut, U.P. We all also highly acknowledged to the Uttar Pradesh Council of Agricultural Research (UPCAR), Lucknow for giving resources to conduct the present research.

\section{Conflicts of interest}

We solemnly declare that there is no conflict of interest to publish this manuscript.

\section{References}

Ahsan MS, Kumar M, Upadhyay JP, Hussain MA, Gupta P K and Singh A 2018 Effect of different doses of Trichoderma harzianum and fungicides for the management of collar rot of chick pea caused by Sclerotium rolfsii. International Journal of Pure Application Bioscience, 6(1): 16561660.

Anonymous 2017 Twelfth plane is the average of APY is the III $^{\text {rd }}$ advance estimate. DPD/ PUB/TR/19 Annual report 2016-17: 35.

Anonymous 2018 Pulses Revolution From Food to Nutritional Security Min. of Agri. \& FW (DAC\&FW), GOI 201718: 9 .

Anonymous 2018 Pulses Revolution From Food to Nutritional Security Min. of Agri. \& FW (DAC\&FW), GOI 2017- 
18: 14.

Bisset J 1984 A revision of the genus Trichoderma I sect. Longibrachiaticum sect.nov. Can. J. Bot. 62: 924-931

Chandel SRS 2002. A hand book of agricultural statistics. Achal Prakashan,Mandir, India. P. 99.101.

El-Mougy NS and Abdel-Kader MM 2008. Long term activity of bio-priming seed treatment for biological control of faba bean root rot pathogens. Australian Journal of Plant Pathology. 37: 464471.

Gaikwad SN, Salve S N and Rajurkar SK 2018. In vitro antagonistic activity of Trichoderma harzianum against soil borne fungal pathogens. International Journal of Biology Research. 2(3): 8789.

Gurha S N and Dubey RS 1982. Occurrence of possible sources of resistance in chickpea (Cicer arietinum L.) against Sclerotium rolfsii Sacc. Madras Agricultural Journal, 70: 63-64.

Harman GE, Howell CR and Viterbo A 2004. Trichoderma species-opportunistic, avirulent plant symbionts. Nature Reviews, 2:43-56.

Hossain I and Hossain MH 2010. Status of tikka disease of groundnut in Bangladesh and effect of BAUBiofungicide on improving seed quality. BAU Research Programme, 20: 29-30.

Kotastthane SR., Agarwal PS, Joshi KK and Sing L 1976. Studies on wilt complex in Bengal gram (Cicer arietinum L.). Jawaharlal Nehru Krishi Vishwa Viddhalaya Research Journal, 10: 257258.

Mahen VK, Mayer CD, Brennemen TB and McDonald D 1995. Stem and pod rots of Groundnut. Information Bulletin No. 4, ICRISAT, India., 28.

Mathur SBand Sinha S 1968. Disease development in guar (Cyamopsis psoraloides DC.) and gram (Cicer arietinum L.) attacked with Sclerotrium rolfsii under different soil $\mathrm{pH}$ conditions. Phytopathology, 62: 319322.

Mawar R, Tomar AS and Singh, D. 2018. Demonstration of efficacy of biocontrol agents in managing soi borne diseases of various crops in arid region of India. Indian Phytopathology, 72: 699-703.

Mukhopadhyay AN 1987. Biological control of soil borne plant pathogens by Trihoderma spp. Indian Journal of Mycology and Plant Pathology, 17: 110.

Nagamma G and Nagaraja A 2015. Efficacy of biocontrol agents against Sclerotium rolfsii causing collar rot disease of chickpea, under in vitro conditions. International Journal of Plant Protection, 8 (2): 222-227

Pandey KK and Pandey P K 2005. Differential response of biocontrol agent against soil pathogen on tomato, chilli and brinjal. Indian Phytopathology, 58: 329-331.

Papavizas GC and Lumsden D 1982. Improved medium for isolation of Trichoderma species from soil. Pl. Dis. 23: 1019-1020

Papavizas GC, Dunn MT, Lewis JA and Beagle RJ 1984. Liquid fermentation technology for experimental production of biocontrol fungi. Phytopathology, 74: 1171-1175.

Saraf CS, Rupela OP, Hegde DM, Yadav R L, Shivkumar BG, Bhattarai S, Razzaque MA and Sattar MA (1998) Biological nitrogen fixation and residual effects of winter grain legumes in rice and wheat cropping systems of the Indo-Gangetic plain. Oxford \& IBH publishing Co. Pvt. Ltd., New Delhi, 14-30.

Shamsuzzaman Islam SMA and Hossain I 2003. Trichoderma culture and germination of sweet gourd seed. Bangladesh Journal of Seed Science \& 
Technology, 7 (1\&2): 91-95.

Singh NP.2010. Chickpea Project Coordinator report, Indian Institute of Pulses Research, Kanpur, 45.

Singh SP, Singh HB and Singh DK 2014. Biocontrol potential of mixture of Trichoderma isolates on damping-off and collar rot of tomato. The Biosean, 9 (3): 1301-1304.

Subash N, Sundaram MM, Sasikumar C and Unnamalai N 2014. Mass cultivation of Trichoderma harzianum using agricultural waste as a substrate for the management of damping off disease and growth promotion in Chilli plants (Capsicum annuum L.). International Journal of Pharmacy and Pharmaceutical Sciences, 5(6): 09751491.

Sultana N and Hossain I 1999. Biological control of foot and root rot of lentil with Trichoderma harzianum. Bangladesh Journal of Seed Science \& Technology, 3(1\&2): 107-111.

Sultana N, Chowdhury MS and Hossain I 2001. Growth and storability of
Trichoderma harzianum and its effect on germination of tomato seeds. Bangladesh Journal of Seed Science \& Technology, 5(1\&2): 117-121.

Vinale F, Sivasithamparam K, Ghisalberti L E, Marra R, Woo LS and Lorito M 2008. Trichoderma-plant-pathogen interactions. Soil. Biology and Biochemistry, 40: 1-10.

Vincent JM 1927. Distortion of fungal hyphae in the presence of certain inhibitors. Nature, 159: 850.

Weber GF 1931. Blights of carrot caused by Sclerotium rolfsii with geographic distribution and host range of the fungi. Phytopathology, 21: 103-109.

Williams PC and Singh U 1987. Nutritional quality and the evaluation of quality in breeding program. In Chickpea CAB International, Wallingford Oxon UK, 329-356.

Yaqub $F$ and Shahzad S. 2005. In-vitro evaluation of microbial antagonists against Sclerotium rolfsii. Pakistan Journal of Biotechnology, 37(4): 10331036.

\section{How to cite this article:}

Anil Kumar, Ramesh Singh Yadav, Kamal Khilari, Prashant Mishra, D. V. Singh, M. K. Yadav and Amit kumar Yadav. 2020. Comparative Study on Biocontrol Potential of Local Isolates with Commercial Formulations of Trichoderma harzianum for the Management of Collar Rot of Chickpea Caused by Sclerotium rolfsii Sacc.. Int.J.Curr.Microbiol.App.Sci. 9(08): 24722484. doi: https://doi.org/10.20546/ijcmas.2020.908.282 